\title{
Om parlamentarismekritikkens potentialer
}

AF S $\varnothing$ REN MAU

SLAGMARK \#72

SIDER: I TI-I77

I Danmark taler vi altid om "vores demokrati", mens sloganet for TV2's valgdækning er "Du bestemmer". Men hvem bestemmer egentlig? Hvordan står det egentlig til med det såkaldte demokratiske politiske system? Nu når der er folketingsvalg, og vi alle får tilsendt små sedler, som kan veksles til en stemmeseddel, som så igen kan veksles til... ja, hvad? Til indflydelse? Givet at vi har stemmeret, hvordan forvalter vi så denne stemmeret på en måde, der er i overensstemmelse med et ønske om et mere demokratisk samfund? Det er nogle af de spørgsmål, jeg har prøvet at besvare i Hovv stemmen! I Danmark diskuterer vi aldrig, hvorfor man egentlig stemmer. Vi forfalder til en abstrakt og farlig forståelse af demokratiet, hvor vi identificerer demokrati med stemmeafgivning (eller en hvilken som helst anden institution). Stemmeafgivning kan være et led i en demokratisk procedure, men det kan også være en måde, hvorpå et udemokratisk system forsøger at give sig selv et skær af legitimitet. Og det sidste, mener jeg, er dækkende for, hvad folketingsvalget i den nuvorende situation handler om.

Hvis vi ønsker at skabe et reelt demokratisk samfund, hvis vi ønsker at fratage den udemokratiske elite sin magt, hvis vi ønsker et samfund, hvor hele befolkningen bestemmer over sig selv, så skal vi ikke regne med at det sker gennem det parlamentariske arbejde alene. Forandringen må (også) komme fra brede, folkelige, sociale bevægelser. Det lader til, at mine kritikere er forholdsvis enige med mig i dette. Dette er en udbredt holdning på venstrefløjen, men det er det desværre ikke i mange 
andre dele af befolkningen. Mit håb er, at en kritik af det politiske system kan åbne op for, at flere vil engagere sig i det udenomsparlamentariske arbejde. Der er i Danmark en udbredt forestilling om, at vi lever i et velfungerende demokrati - og dele af venstrefløjen i Danmark udbreder endda denne forestilling (f.eks. Enhedslisten, der i deres principprogram skriver at "vi har frie og demokratiske valg"). Mit håb er, at en nedbrydning af denne forestilling kan åbne op for en form for udenomsparlamentarisk demokratisk engagement i større skala end det, vi i øjeblikket ser.

\section{FRA KRITIK TIL HANDLING}

Dermed adresserer jeg det spørgsmål om forholdet mellem kritik og handling, som både Hansen og von Eggers rejser. Der er (desværre) ikke en lige, simpel vej fra kritik til handling, og den kritiske afdækning kan altid risikere at gå til spilde i resignation og kynisme. Dette er et vilkår for al kritik. Men jeg tror heller ikke, at kritik aldrig kan være et skridt på vej mod handling. Der er ingen nødvendig modsætning mellem kritik og handling. Og desuden er kritik, som von Eggers påpeger, også i sig selv en handling. Kritik kan føre til handling, men gør det ikke altid. I den forbindelse er det vigtigt at påpege, at jeg ikke har nogen forestilling om, at opfordringen til at lade være med at stemme kan udgøre et selvstændigt grundlag for mobilisering. Mit eneste håb er, at en kritik af det politiske system kan gøre det nemmere for sådanne bevægelser at mobilisere og rekruttere ved at udbrede fornemmelsen af, at vi bliver nødt til at organisere og mobilisere, hvis vi vil skabe forandringer. Med von Eggers' ord: "Ideologikritikken åbner således for muligheden af, at det kunne være anderledes og får os til at lede efter praksisser, der bryder med den herskende ideologi”. Derfor peger jeg heller ikke på konkrete bevægelser, som jeg opfordrer til, at man tilslutter sig. Det ville svække bogens kraft, hvis den sluttede af med en opfordring til at deltage i G7-protesterne, Blockupy, Bloker Boretårnet, blive fredsvagt i Palæstina osv. - bogen ville ende med at fremstå som en snedig måde at rekruttere til bestemte bevægelser på.

Dog er det vigtigt at have med, at jeg ikke bare har skrevet en bog. Jeg har sammen med andre stablet en gruppe på benene ("Stem ikke til folketingsvalget!"), der har afholdt offentlige aktionsmøder i København og Århus, skrevet et manifest sammen og som vil lave aktioner op til valget - netop for at undgå, at det "ikke at stemme" ligesom stemmeafgivning bliver "en individualiseret handling". Ved at lave 
aktioner og møder om emnet, forsøger vi netop at give os selv og andre en mulighed for at tage aktivt del i en kollektiv protest mod det politiske system, ligesom vi på den måde knytter kontakter og opbygger og udveksler aktivist-erfaringer, der kan skabe grobund for mobilisering omkring andre politiske projekter i fremtiden.

\section{IMOD DEN ABSTRAKTE DEMOKRATIFORSTÅELSE}

Både Rune Møller Stahl, Bue Rübner Hansen og Lotte Folke Kaarsholm henviser til valg $i$ andre lande og andre historiske perioder og fremdrager disse eksempler for at illustrere, at det parlamentariske arbejde kan være en effektiv del af en progressiv og demokratisk politisk strategi - hvilket jeg er helt enig i. Så for at svare på Hansens spørgsmål: ja, jeg ville stemme til lokalvalget i Barcelona. Som jeg skriver på bogens første side, har jeg intet imod valg, og jeg har heller ikke noget imod repræsentation (som Stahl lader til at tro). Min pointe er sådan set blot: parlamenter og repræsentation er ikke i sig selv progressive og demokratiske - de kan være et led både i en demokratisk politisk kamp og en måde at opretholde en udemokratisk tilstand på. I den nuværende situation i Danmark mener jeg, at Folketinget har den sidste funktion. Men i en anden situation, hvor der f.eks. eksisterer en reel demokratisk, social bevægelse (som f.eks. i Spanien lige nu), kan parlamentet selvfølgelig godt fungere som det første.

Jeg er derfor helt på linje med Stahl, når han henviser til situationen i Latinamerika, Grækenland og Spanien som eksempler på, hvordan "kombinationen af folkelig mobilisering og parlamentariske regeringer faktisk er i stand til at bryde den neoliberale udvikling", og jeg vil netop gerne være med til at skabe den folkelige mobilisering, der mangler i Danmark. I den forbindelse vil jeg dog uden at gå ind i en grundig diskussion blot bemærke, at situationen i Grækenland stadig er så åben, at den ikke tillader en konklusion, hvad angår det parlamentariske arbejdes nyttighed for en social bevægelse, der forsøger at modarbejde Trojkaens neoliberale afpresning af den græske befolkning. Som Hansen nævner i forbifarten, har Syrizas modstand desværre indtil videre været "stort set forgæves". Jeg håber, at det ændrer sig, og jeg håber, at den græske befolkning lykkes med at bruge parlamentet til at bekæmpe Trojkaen, og der er ingen grund til at opgive den kamp nu - blot vil jeg understrege, at man ikke uden videre kan bruge Grækenland som et eksempel på, hvordan en social bevægelse i forening med parlament og regering kan udgøre en 
stærk front mod neoliberal afpresning. Desuden er det vigtigt at have med, at en af de ting der netop bliver mobiliseret omkring i Spanien, er (som Hansen også peger på) utilfredsheden med det etablerede politiske system, og ikke "et offensivt forsvar for det truede parlamentariske demokrati" (som Stahl mener, der er brug for - hvad er det for et demokrati, han taler om?). Erfaringen fra Spanien viser faktisk, at det er muligt at mobilisere bredt omkring bl.a. utilfredshed med det etablerede politiske system - med andre ord, at kritikken af partierne, parlamentet og medierne faktisk kan være en del af et grundlag for en demokratisk, folkelig mobilisering.

Derfor mener jeg, at Stahl og især Kaarsholm fejllæser bogen. Man kan på ingen måde slutte noget som helst vedrørende stemmeafgivning i Afghanistan (eller nogle andre steder) ud fra Hovv stemmen! Kaarsholms inddragelse af det afghanske valg antyder en abstrakt forståelse af demokratiet, idet den implicit sidestiller det afghanske valg og folketingsvalget i Danmark anno 2015. Det er forskellige situationer, og i vurderingen af dem må man være sensitiv over for disse forskelle. Stemmeafgivning kan godt være en progressiv handling i en bestemt situation, samtidig med at det kan være det modsatte i en anden situation. Jeg afviser derfor ikke tidligere "tilkæmpede sociale og institutionelle fremskridt", som Stahl skriver, hvilket jeg også eksplicit skriver i bogen angående udvidelsen af stemmeretten i 1915:

Kampen for kvinders og fattiges stemmeret var ubetinget progressiv. I den konkrete historiske situation, som de befandt sig i, var det uden tvivl det rigtige at kæmpe for at få stemmeret. Dem, der dengang kæmpede for at udvide stemmeretten, kæmpede for de marginaliserede befolkningsgruppers politiske indflydelse, de kæmpede for et mere demokratisk samfund. Det er den samme kamp, vi må kæmpe i dag - mod illegitime magthierarkier, hvor de få bestemmer over de mange, og for en demokratisk politisk praksis, hvor alle bestemmer over alle, eller anderledes udtrykt: hvor samfundet bestemmer over sig selv. Den historiske udvikling har skabt en situation, hvor vi på paradoksal vis må kæmpe denne kamp ved at gøre det modsatte af, hvad de progressive kræfter gjorde for hundrede år siden: I stedet for at kæmpe for at blive integreret i det politiske system, må vi kæmpe mod og på trods af det (s. 76f).

Bogen understreger således, at vurderingen af det parlamentariske arbejdes nyttighed for en demokratisk politisk praksis altid må bero på en konkret analyse af den konkrete situation - i modsætning til Kaarsholms abstrakte tilgang. Var stemmeafgivning til folketingsvalget progressivt i 1915? Sandsynligvis (jeg har ikke un- 
dersøgt situationen nærmere). Er stemmeafgivning til folketingsvalget progressivt i 2015 ? Nej. Det er simpelthen unuanceret, ahistorisk og abstrakt at tro, at deltagelse i valg altid er den rigtige strategi for en demokratisk politik. Ligeså abstrakt og ahistorisk vil det være at sige det modsatte, hvilket en tænker som Alain Badiou tenderer til. Min primære inspiration til kritikken af den danske parlamentarisme kommer ikke fra Badiou, hvilket Stahl antyder. Badious ontologisering af statsbegrebet får ham til a priori at afvise enhver politisk praksis inden for staten til fordel for en politik "at a distance from the state" - her er jeg enig med Žižek, der kritiserer Badiou for at have en "overblown notion of the state".

I tråd med denne afvisning af en abstrakt forståelse af demokrati, ser jeg heller ikke demokratiet som "en (tabt) tilstand", hvilket Kaarsholm insinuerer. Et citat fra bogen, hvor jeg parafraserer Marx og Engels, burde være tilstrækkeligt her: "Demokrati er ikke en tilstand, der skal skabes, et ideal, som virkeligheden har at rette sig efter" (s. 79). Faktisk understreger bogen, at demokratiet altid kun eksisterer som en konkret, historisk praksis, og ikke kan identificeres med en tilstand eller en institution (som f.eks. valg) (s. 18-19).

Kaarsholm kritiserer mig for at have en for renfærdig definition på det politiske, fordi jeg skriver: «Den politiske stillingtagen skal tage udgangspunkt i spørgsmålet: 〈hvad er bedst for alle?» og ikke spørgsmålet: Hvad tjener bedst mine interesser?». Dette er ifølge hende "en fantasi, der aldrig har været virkelig". Det hævder jeg heller ikke, at den har været. Jeg skriver netop, at den politiske stillingtagen skal tage udgangspunkt i spørgsmålet "Hvad er bedst for alle?", jeg skriver ikke at den rent faktisk gør det. Tværtimod understreger jeg: "Mennesker danner ikke deres holdninger i et socialt tomrum. Hvem man er, hvordan man ser verden, hvad man mener om diverse politiske ting og sager, er i høj grad afgjort af de miljøer, man dannes og færdes i" (s. 66), men jeg forklarer også, hvorfor dette ikke udgør en barriere for universalismen: "Det universelle eller almene perspektiv nås ikke ved at abstrahere fra ens kulturelle og sociale udgangspunkt, ikke ved at aktivere en eller anden 'fornuftsevne', som gør os i stand til at hæve os op over det konkrete, levede liv - men tværtimod ved at gå helt ind i en kulturel formation, blotlægge dens modsigelser, og kæmpe de kampe, der udfolder sig dér" (s. 69). Folk handler faktisk på en universel måde og tilsidesætter deres egne interesser. Kaarsholm opererer med en for simpel og udialektisk modstilling af det partikulære og det universelle eller mellem egeninteressen og alles interesse. Disse kan sagtens være sammenfaldende (men 
de kan også være modsatrettede). Her er jeg på linje med f.eks. Marx, der netop i arbejderklassens egeninteresse ser den universelle interesse.

\section{DEMOKRATIET, MAGTEN, PROFITTEN}

Kaarsholm udbreder til sidst nogle mærkværdigheder om Folketinget. Ifølge hende bruges Folketinget til hverdag til at stille magthavere til ansvar. Hun giver som et eksempel, at ministre kan tvinges til at svare på spørgsmål. Men ministrene er jo ikke magthaverne - de er bureaukrater. De magthavere (eller den struktur, der fungerer som magtinstans), bogen peger på, og som er uden for Folketingets rækkevidde, er først og fremmest den globale økonomis bevægelser. Og hvordan Folketinget kan stille disse bevægelser til ansvar, er mig en gåde. Kaarsholm anfører, at vi kan stille krav til multinationale selskaber. Ja, det kan vi, men kun så loenge vi ikke truer deres profitabilitet - hvis den bliver truet, så vil de ikke føre forretning i Danmark, hvilket er nødvendigt i en kapitalistisk økonomi (som selvfølgelig ikke selv er nødvendig). Dette er ikke noget nyt, hvilket også bemærkes i bogen. Men den fleksibilitet, virksomhederne med udviklingen i den internationale økonomi de seneste årtier har fået, udhuler i endnu højere grad end tidligere den mulighed, nationale regeringer og parlamenter har for at gå op imod virksomhedernes udemokratiske magt, når befolkningen ønsker dette. Kort sagt: Ja, Folketinget og regeringen kan godt kræve alt muligt af virksomheder (inkl. finanssektoren), men kravet om profitabilitet sætter stadig en effektiv grænse for disse krav. Demokratiet stopper ved kravet om profit. Hvis en demokratisk beslutning truer profitten, er det altid profitten, der vinder.

Folketinget er altså på ingen måde "et redskab til at praktisere en lighedsskabende dynamik mellem folket og magten", og i øvrigt betyder demokrati ikke en lighed mellem folket og magten, men en identitet mellem disse to og en nedbrydelse af skellet mellem regerende og regerede. Folketinget har muligvis haft en demokratisk funktion tidligere, men det er ikke den funktion det har i dag. I dag er Folketingets funktion af få det til at se ud som om vi lever i et velfungerende demokrati. Det er ikke en "en projektør", som Kaarsholm skriver, men tværtimod en mørkelygte, der ved at sætte sig selv i fokus forskyder fokus (og derved mørklægger) de reelle magtstrukturer, som kendetegner det 21. århundredes kapitalistiske system. 


\section{STEM IKKE!}

En demokratisk kritik af det politiske system i Danmark kan være en del af et forsøg på at nære de sociale bevægelser, der kæmper mod den neoliberale kapitalismes undergravning af demokratiet. Denne kritik er alt for fraværende. Vi mangler en kritik af "tendensen til at reducere demokrati til parlamentarisme" (Hansen). Stemmeafgivningen står mejslet i sten som inkarnationen af den platoniske idé om Demokratiet, i stedet for at blive vurderet som det, den er: en proces, der i sig selv hverken er progressiv eller reaktionær, demokratisk eller udemokratisk, men som derimod kun får sin betydning fra den konkrete politiske praksis og de institutioner, den eksisterer i. Mod den abstrakte og essentialistiske opfattelse af stemmeafgivningen bør vi derfor (som altid) sætte den konkrete analyse af den konkrete situation.

I den nuværende situation er der et potentiale for mobilisering ved at knytte an til den udbredte politikerlede i den danske befolkning, og jeg håber derfor, at Hov stemmen! og den aktivisme og propaganda, vi bedriver i gruppen "Stem ikke til folketingsvalget!" med Hansens ord "præciserer en forståelse, eller rationaliserer en følelse, der er delt af langt flere, end den politiske elite forestiller sig". Derfor har jeg skrevet Hov stemmen!, og derfor opfordrer jeg fortsat til (sammen med os andre) at udtrykke en kollektiv protest mod det politiske system ved at lade være med at stemme til folketingsvalget. Forhåbentlig vil bogen være dybt irrelevant ved næste folketingsvalg. 